\title{
Utilizing a Recorded-Video to Assess Speaking and Presentation Skills of Pre-Service Teachers
}

\author{
Siane Indriani \\ siane.indriani@uph.edu \\ Universitas Pelita Harapan
}

\begin{abstract}
Teachers have employed in-class oral presentations to practice the pre-service teachers' speaking skills as they are prepared to become future English teachers who are fluent in communication using English in a globalization era, However, effectively assessing student presentations is challenging, particularly in terms of practical administration of assessment. Therefore, a video recording as an alternative assessment tool was utilized to provide opportunities for learners and their peers to evaluate their speaking and presentation skills. They will need to combine video-camera on their cell phones or tablets and the use e-google form to give immediate feedback for their improvement. The study used a qualitative descriptive method. The data were gathered from the students' recording videos, reflective journal, feedback from e-google form. The results showed that students got more enthusiastic in presenting their ideas using the video-camera. Furthermore, presentation skills such as the use of eye contact, body posture, and voice were found as other factors that supported the English speaking skills of the pre-service teachers.
\end{abstract}

Keywords: Pre-Service Teachers, Video Recording, Speaking Skill, Presentation Skill

Received date: 9 Agustus 2019

Article Info

Revised date: 6 Januari 2020

Accepted date: 22 Januari 2020

\section{INTRODUCTION}

Assessing student's speaking and presentation skills could be a challenging task, especially in terms of effectiveness and practicality. It involves lengthy, time-consuming assessment and evaluation of students' performance, while actually with the help of technology, the problem can be resolved easier. Students usually would like to get some feedback soon after they have finished their presentation. They may expect to know what areas that they have done well and areas that need to be improved. Therefore, utilizing integrated assessment tools of a recorded-video and e-google form seems very promising. In other words, both the teacher and the students will find it very helpful in relation with flexibility, effectiveness, and practicality. The students can record their speaking and presentation video outside the classroom, while the teacher can do something else rather than watching the students' performance alive in the classroom. However, it does not reach a satisfying result. Due to technological advances, educators need to be aware of both the benefits and challenges of integrating technology within students' learning process.

The biggest challenge faced by both teachers and students in a second language or foreign language learning processes is the use of targeted language that is decreasing because of the lack of confidence. This condition will lead to ineffectiveness in the progress of language skills developed in the face-to-face interaction in the classroom. Teachers need to find a solution that will make the students get more improved in their language class that might be enhanced through activities outside the classroom, so that they students will be more engaged in their own learning process both inside and outside the class affectively. Therefore, the combination between recorded-video with face-to-face instruction have been found to promote the students' L2 or foreign language learning to be conducted effectively as they can give students flexibility to work independently, at their own pace, motivating, and appropriate to students' learning needs leading to autonomous learning process (Kurkgöz, Y, 2011). It usually requires students to attend traditional face-to-face classes and to work independently with a synchronous and/or asynchronous communication tool. It brings impact on the students' motivation as they are more comfortable with technology because it suits more on their mobile interaction with others 
around the world. It was hoped that teachers can have strategies related to the advancement in digital technology nowadays that should not only make people's lives easier and comfortable, but it also should bring people to acknowledge their potential and intelligences to be able to contribute significantly in the society where they live.

As what the previous research suggested that the use of video recording strategy in the face-toface instruction is to represent L2 or foreign language learning resource integrated on their personal devices, such as cell phones or tablets as people around the world had experienced the mobile interaction within the complexity of the today's technology era. Furthermore, educators are challenged to utilize the students' personal video-camera to become better speakers of English. Similarly, the students can have opportunities to watch their speaking performance through the recorded-video more than once. Thus, video recordings allow students to replay the video as many as they can make a self-evaluation on what they have planned and successfully done. As a positive consequence, students become selfcritical because they can see their problems and trace their improvements. Moreover, video-recording gives space for a learning community to happen. Students can watch and see themselves and their fellow friends' performances. In addition to that, it is good to get feedback from the fellow friends or peers as well as from the lecturers. It is necessary to see how the students see the value if using the technology integrated learning on their speaking performance in combination with face-to-face interaction. This study aims to investigate the use of recorded-video to assess students' speaking and presentation skills in their language learning and how they see the value of integrating technology within the learning process.

\section{LITERATURE REVIEW}

There are many ways to facilitate self-access language learning using technology, but having a flexible and easy access to recording tools can support the unlimited communicative practice that assists language learners in building knowledge for communicative competence (Castellano, Mynard, \& Rubesch, 2011: 110). Using a recorded-video presentation is an alternative assessment method to provide an autonomous learning environment in which learners can practice speaking and check their performance to monitor their learning progress (Kırkgöz, Y, 2011: 54). Autonomous is an extent where students demonstrate the ability to take control of their own learning (Sanprasert, 2009: 100).

In order to build an autonomous learning within the learners, there should be trust built in as one class community, so that everyone will take responsibility in order to contribute to the success of the whole community. As what Brummelen (2009) stated that trust and mutual understanding among the community will provide an environment where students develop a positive contribution to the classroom community. Other than that, a positive environment will encourage each other. One of the strategies to do that is through giving feedback for students' progress. As stated by Gromik (2012: 105) that students would be more challenged if there is an immediate feedback towards what they have done to improve their skills in the future. Both the teacher and learners need to continue making meanings for every individual to keep on growing where love for one another becomes the center of interaction (Greene, 1998: 115).

Based on the previous research results, teaching the millennial generations who are digital natives, learning can happen everywhere with any kinds of devices and it is no longer focuses on the teacher or one-way-teaching (Drath \& Horch, 2014: 56; Alqahtani, 2014: 20; and Han, 2015: 43), but more on the students. An autonomous learning will only happen when the learner can find connection between what they are learning and their interests. In this advanced technology, people can access information anywhere they like using any kinds of devices. It again gave them autonomy towards their learning process in terms of the time used for presenting their ideas. This flexibility has increased the use of video-cameras in various learning environments. It was supported by the use of media technologies that allow users to record audio and video files in a reasonably short amount of time leading to the increased use of video cameras in lecture halls and other learning environments (Odhabi \& Nicks-McCaleb, 2011:90). Then, the learners can also monitor the progress of their speaking and communication skills from the recorded video produced. By using the video-camera on their own devices on also gave them a personal flexibility in editing, revising, and adjusting their recorded-video anytime they want. Moreover, they can share their videos to others and get feedback on their speaking and presentation skills, especially in English which is a foreign language for them. 


\section{RESEARCH METHODOLOGY}

The study used a qualitative research methodology that involved 34 students who learned basic grammar in English class. They were asked to record their speaking and presentation practices by using video camera on their own cell phones or tablets, even they can also use their own portable camera. After they have finished recording their speaking presentation, they needed to upload their recordedvideo in the drive on their class email account. Their videos would be able to be accessed by their peers and teacher. Whoever watched their videos would be asked to give feedback to improve and evaluate what they have done. The study used instruments such as the students' recorded presentation video, student's reflective journal and peer-feedback using the e-google form to gather data. Their peers gave scores on each criteria used to assess their speaking and presentation skills from 1-3 showing the least to the highest scores. The peers also gave comments or feedback descriptively. Both the scores and descriptive comments were recorded using the e-google-form. At the end of the study, each student was asked to reflect on how they went through the recording process and how they found themselves improved in their language skills, especially in speaking skill. After all data were gathered, they were analyzed descriptively with supporting theories. The result was drawn from a comprehensive discussion result of all documents analyzed from different instruments.

\section{FINDINGS AND DISCUSSIONS}

Based on the data gathered from the students' recorded video, it was found that each student could perform their speaking skill well in expressing their ideas in an effortless, smooth, and at an appropriate speed. Their presentations were also enjoyable and engaging with appropriate gestures, eyecontact, and facial expression. Their speaking and presentation skills look more natural in a way they choose certain face expression while delivering their ideas and tone used to put emphasis on a particular topic they raised autonomously. Other than that, through sharing their topics, they could enhance their critical thinking skill to analyze and decide strategies to solve problems based on related contexts.

From their reflective journal, it could be seen that students' enthusiasm to speak in English recorded using the video-camera on their own devices on also gave them flexibility in editing, revising, and adjusting their recorded-video anytime they want. They found that recording their speaking practice using their own video-camera has given them more personal flexibility. Here are some comments they stated on the e-google form regarding to what they felt about their speaking practice using the videorecording.

Student A : I feel more comfortable recording my speaking practice in English using my own

video-camera on my cell phone.

Student B : I feel more confident practicing my English using my own device since I don't need to speak in front of the class.

Student B : I started with making a draft of what I am going to say in my video, then I can practice my English and edit it as many as I want.

So, the data can be inferred that this kind of learning had given the students more personal room to improve and to practice speaking in English in more relax situation along with eye-contact, body gestures, and a clear voice in their presentation. They do not need to be afraid of speaking in front of the class where all their fellow friends will look at them directly. They took in charge over their own learning process because they could adjust it according to their situation. In fact, there are many ways to facilitate self-access language learning using technology, but by having a flexible and easy access to recording tools, it can support the unlimited communicative practice that assists language learners in building knowledge for communicative competence (Castellano, Mynard, \& Rubesch, 2011: 159).

Being able to record their speaking and presentation using a video-camera also challenged the students to think out of the box. They were challenged to go beyond what they could think of they were able to do, a part of the lack of their English speaking skill, such as grammar accuracy, fluency, and confidence, they could have a self-evaluation towards their own performance and get improved. Based on the data recorded from the e-google, $99.2 \%$ of the students commented that their friends were more 
confident in their speaking. They could present their topic fluently. There were only $28.3 \%$ of the students suggested their friends to practice more on their speaking skill and use a louder voice while they were presenting their ideas on the camera. All students agreed that their friends still need to improve their grammar in their speaking performance. However, they found a positive value from what they commented towards their peers' speaking performance.

Student A gave feedback on Student B's video: You could present your ideas confidently, but you need to improve your grammar (:)

Student C gave comments on Student D's video: You need to speak louder next time. Practice makes perfect $(-)$

By using a recorded-video presentation, it is an alternative assessment method to provide an autonomous learning environment in which learners can practice speaking and check their performance to monitor their learning progress (Kırkgöz, Y, 2011: 97). Furthermore, the students can also express their opinions towards their fellow friends as they are in one community. There is a need to support each other to grow together, it could be in terms of suggestion, feedback, or even corrections on what they have done. To maintain the same enthusiasm in the classroom as one community, there should be trust built in the community, so that everyone will take responsibility in order to contribute to the success of the whole community. As what Brummelen (2009: 124) stated that trust and mutual understanding among the community will provide an environment where students develop a positive contribution to the classroom community.

Student A: It is a great experience for me to be able to record my speaking performance using my own video-camera on my cell phone. I can replay the video as many as I want and I can edit it to make my performance better. I am opened for any feedback from my friends.

Student B: I am more relax speaking in front of the camera on my own cell-phone. I know that I need to improve my grammar, but I also know I and my friends are all growing together.

Their English fluency was also performed well in their speaking supported by the use of an eyecontact, body posture, and voice used in the recorded-video. It is a great thing to get an immediate feedback from the fellow students or teachers because it will create a meaningful learning process which is definitely needed for every individual's continuous improvement. As stated by Gromik (2012: 67) that students would be more challenged if there is an immediate feedback towards what they have done to improve their skills in the future. Furthermore, the students got involved in a more interactive way with their friends because they can give positive comments or constructive feedback toward their friends' speaking and presentation skills from their recorded-video. This will lead to a continuous meaning learning process for every individual to keep on growing where love for one another become the center of interaction (Greene, 1998: 98). Social interaction is also necessary in an autonomous learning because things that students learn will be constructed through communications amongst others and it gives more chances for them to make evaluation towards their performances. This also leads them to be able to be wiser user of technology devices, such as smart phones, internet, YouTube, social media, and others. Through the use of social media and you tube, the learners put more attention on the materials or the content and be more autonomous learning English as a foreign language (Watkins, 2011: 24). They are more aware of how social media can help the language learners to be more autonomous towards their own learning and through the use of technology on the digital devices can also support their engagement with the content they are going to present. Not only that, the learners' comprehension skill is also improved throughout the learning process since they prepare the materials and present them using their own ideas and strategies (Paramita, H., \& Sihombing, M., 2017: 24).

The use of video-recording could also give benefit for the students in expanding their vocabularies and word-choices within a 3-minutes recorded video. They were given chance to prepare for their recorded-video in 2 weeks long. They had to practice speaking in English before they recorded their 3-minutes speaking in front of the camera. In their reflective journal, they said that they enjoyed the learning process because they could learn to speak in a more effective way since they needed to decide only to say the necessary information related to their topics without direct supervision from the 
teacher. It again gave them autonomy towards their learning process in terms of the time used during the presentation. This flexibility has increased use of video-cameras in various learning environments. It was supported by the use of media technologies that allow users to record audio and video files in a reasonably short amount of time leading to the increased use of video cameras in lecture halls and other learning environments (Odhabi \& Nicks-McCaleb, 2011: 78). Through the learning process, they are able to decide strategies to enhance their self-independent learning. It was confirmed that an autonomous learning represents the ability of the learners to decide their learning strategies by acknowledging the capacity of self-independent and self-instruction learning (Shao-Yue, 2009: 165).

\section{CONCLUSIONS}

By using their mobile phones or tablets, it offers flexibility because the students can adjust the content anytime and anywhere they want. The use of camera on the students' own cell phones and use them to record their speaking and presentation skills made it private and flexibly adjusted according to the their' situation. It also gives a positive impact on students' viewing and critically evaluating their speaking tasks. The use of technology has supported the students to take control over their own learning process. They are also able to evaluate their speaking and presentation skills from the videos they have made. Attention is more drawn to a number of potential advantages of integrating technology into faceto-face instruction as well as intrinsic motivation had the students to speak in English with their peers. Though there were grammatical mistakes had by the students, but they were able to perform fluency in expressing their ideas in a natural way. This also was supported by their presentation skills, such as the use of eye-contact, body gesture, and voice that were performed well during the recorded-video speaking and presentation performance. It is possible to use the video recording feature to evaluate learners' speaking skills, especially because they can get an immediate feedback to improve their skills as well an alternative assessment tool to have a self-evaluation on their own progress that will be aligned with the need of autonomous learning. They become more aware of the use of the technology nowadays, so that the autonomous learners can utilize technology-based devices more wisely, so that it can support their learning process and help them to produce the more effective results that will bring impact to the wider community. They could also build up their vocabularies and word choices that they will use within 3 minutes presentation.

For future research, it was suggested to use the recorded-video strategy to improve the students' speaking and presentation skills that require a collaborative work of students. It is to maintain the enthusiasm as one learning community in order to maximize the students' confidence in speaking and presenting their ideas in English. It is expected that they will become more confident speakers of English as they are going to become the role models for their students in the future.

\section{REFERENCES}

Brummelen, Vann. (2009). Walking with God in the classroom. Colorado: Purposeful Design Publications.

Castellano, J., Mynard, J., \& Rubesch. T. (2011). Student technology use in a self-access center. Language Learning \& Technology Journal, 15(3), 12-27

Drath, R., \& Horch, A.. (2014). Industrie 4.0: Hit or hype? IEEE industrial electronis magazine, pp. 56-8. Retrieved from ieexplore.ieee.org.http://ieeexplore.ieee.org

Greene, A. (1998). Reclaiming the future of Christian education. Colorado: Purposeful Design Publications.

Gromik, N. A. (2012). Cell phone video recording feature as a language learning tool: A case study. Computers and Education, 52(1), 238-250

Holec, H. (1981). Autonomy and foreign language learning. Pergamon Press.

Kırkgöz, Y. (2011). Blended learning study on implementing video recorded speaking tasks in taskbased classroom instruction. The Turkish Online Journal of Educational Technology, 10(4), $154-167$ 
Scholaria: Jurnal Pendidikan dan Kebudayaan, Vol. 10 No. 1, Januari 2020: 60-65

Odhabi, H., \& Nicks-McCaleb, L. (2011). Video recording lectures: Student and professor perspectives. British Journal of Educational Technology, 42 (2), 327-336.

Paramita, H., \& Sihombing, M. (2017). Students' autonomy in utilizing social media. 7th MELTA International Research Conference in English Language Education 2017. Kuala Lumpur: MELTA.

Sanprasert, N. (2009). The application of a course management system to enhance autonomy in leaning English as a foreign language. System, 109-123.

Shao-yue, W. (2009). A study of network-based multimedia college English. US-China Foreign Language, 38-55.

Watkins, J. (2011). Using YouTube in the EFL Classroom. Using YoutTube in EFL classroom. Language Education in Asia, 113-119. 